$\xi=$

\title{
Characterization of best naringinase producing fungus strain isolated from palmyrah (Borrasus flabellifer) fruit pulp
}

\author{
Sinthuja Karuppaija ${ }^{1 *}$, Ranganathan Kapilan ${ }^{2}$, Vasantharuba Seevaratnam ${ }^{1}$ \\ ${ }^{I}$ Department of Agricultural Chemistry, Faculty of Agriculture, University of Jaffna, Sri Lanka \\ ${ }^{2}$ Department of Botany, Faculty of Science, University of Jaffna, Sri Lanka \\ *Corresponding author E-mail:ranganat@ualberta.ca
}

\begin{abstract}
Background: The Palmyrah (Borrasus flabellifer L.) fruit pulp has the bitter compound flabelliferin (a tetraglycoside) which can be hydrolyzed by naringinase enzyme. The diverse groups of filamentous fungi and bacteria that live in different substrates have the capacity of producing extracellular naringinase enzyme which is of tremendous industrial value.

Objective: The objective of the study was to isolate the naringinase producing fungal strains from Palmyrah and to identify the best naringinase producer under liquid and solid state fermentation systems.

Methods: Fungal strains isolated from Palmyrah fruit pulp and the soil where pulp is allowed to decay, were grown on naringin agar selective medium at $\mathrm{pH} 6.0$ at room temperature and the production of extracellular naringinase was measured in the liquid fermentation media and solid state fermentation system using paddy husk as support.

Results: Five fungal strains isolated from the palmyrah pulp and the pulp decaying in sand designated as PF1,PF2,PF3,PF4 \& PF5 had the ability to produce extracellular naringinase enzyme in liquid fermentation media. Fungal strain PF4 that showed highest naringinase enzyme activity $(1.769 \mathrm{U} / \mathrm{ml})$ was selected among the isolated five fungal strains and identified as Rhizophus stolonifer based on the morphological and biochemical characteristics. When this strain was grown in the solid state fermentation system using paddy husk as media, narininase production was higher (269.84 U/gram of dry substrate) in seven days.

Conclusion: Rhizophus stolonifer could be used to produce large scale naringinase enzyme under solid state fermentation system using very cheap, easily available, agricultural waste paddy husk as support without the need of expensive and well equipped laboratories.
\end{abstract}

Keywords: Naringinase; Paddy Husk; Palmyrah Pulp; Rhizophus stolonifer.

\section{Introduction}

Palmyrah (Borrasus flabellifer L.) is one of the abundant palm in the dry zone of the northern and southern part of Sri lanka. It is said as "the life of tree" because almost all part of the tree has economic value. Potentially a lot of food and beverage items are prepared from the Palmyrah fruit pulp for the commercial purpose in the developing countries like, India, Pakistan, Bangaladesh and Sri Lanka. Even though the demand of the food products is substantially high, a certain percentage of consumers complain about the bitterness of the fruit pulp that lead to the unacceptable quality. Due to this reason, more than half of the annual production of Palmyrah fruits are thrown away and used as animal feed (Jansz et al, 2002). Traditionally a lot of methods like heat treatments and chemical methods are in practice to reduce the bitterness of the food and beverages of the Palmyrah pulp but these methods are less effective and economically unfavorable.

The bitter compound that present in the palmyrah fruit pulp is flabelliferin (Fii) which is identified as a tetraglycoside (Nikawela et al, 2000, Nikawela et al, 2011and Jayaratnam, 2015). The flabelliferin (Fii) can be hydrolyzed into rhamnose and glucose molecules and $40 \%$ of bitterness of flabelliferin (Fii) can be hydrolyzed by $\alpha$-amylase and some are not susceptible to $\alpha$-amylase (Jansz et al, 2002 and Zhang et al, 2007). All the bitter compound of flafelliferin (Fii) can be hydrolyzed by the glycolytic enzyme naringinase (Jansz et al, 2002 and Jayaratnam 2015). The nar- inginase is a complex enzyme which has $\alpha$-L-rhamnosidase and $\beta$ D-glucosidase activities that leads to potential usefulness in pharmaceuticals and food industries (Ribeiro 2011). In recent years, naringinase enzyme is widely used in debittering of palmyrah cordial, jams and citrus juice industries (Jansz et al, 2002 and Kumar et al, 2010). The naringinase enzyme can be produced naturally from plants, fungus and bacteria. There have been some studies on the filamentous fungi like Penicillium sp, Aspergillus $\mathrm{sp}$, Rhizopus sp and those studies confirmed that these organisms have the ability to produce naringinase enzyme (Mendoza-Cal 2010) when the growth substrate contains bitter compound like Naringin (flabelliferin).

In the case of naringinase production at the commercial level, the filamentous fungus might take an ideal option for their cost effective and economically viable in nature than the chemical methods of naringinase production. Since there have been no reports about isolating a naringinase producer from underutilized Palmyrah pulp and its decay in soil, it was planned to work on this area. The objective of the study was to isolate naringinase producing fungal strains from the fruit pulp of palmyrah and its decay in soil and to characterize the best naringinase producer under liquid and solid fermentation system.

\section{Materials and methods}

\subsection{Source of organisms}


Decaying palmyrah fruit pulp and buried fruit pulp in the soil for two weeks, were the sources of organisms.

\subsection{Chemicals}

Naringin, Potato dextrose agar(PDA), Glucose, Peptone, Yeast extract, $\quad \mathrm{KH}_{2} \mathrm{PO}_{4}, \quad \mathrm{MgSO}_{4} \cdot 7 \mathrm{H}_{2} \mathrm{O}, \quad \mathrm{ZnSO}_{4} \cdot 7 \mathrm{H}_{2} \mathrm{O}, \quad \mathrm{CuSO}_{4} \cdot 5 \mathrm{H}_{2} \mathrm{O}$, $\mathrm{FeSO}_{4} .7 \mathrm{H}_{2} \mathrm{O}$, DNS solution

\subsection{Isolation of naringinase producing fungus}

The isolation of naringinase producing fungus was carried out as follows: The decaying fruit pulp and soil buried fruit pulp were taken to made serial dilution up to $10^{-6}$ and $1 \mathrm{ml}$ was inoculated on $0.1 \%(\mathrm{w} / \mathrm{v})$ naringin and $0.5 \%(\mathrm{w} / \mathrm{v})$ glucose agar medium but the soil sample around buried fruit was taken and mixed with sterile distilled water and the filtrate was taken to dilute until $10^{-4}$ from diluted sample, $1 \mathrm{ml}$ was inoculated on the above medium. After 3 days, based on the morphological observations, every fungal strains were sub-cultured on the freshly reared medium until pure cultures were obtained. Five different fungal strains with different morphological and cultural features were obtained. These five fungal strains (labeled as PF1, PF2, PF3, PF4\& PF5) were inoculated on $0.2 \%(\mathrm{w} / \mathrm{v})$ naringin and $0.2 \%(\mathrm{w} / \mathrm{v})$ glucose agar medium to screen naringinase producing fungus based on the colour change of the medium. Secondary screening was also conducted by testing the naringinase enzyme by the assay method (Sinthuja et al. 2016). The isolated fungal strains were sub-cultured on PDA slant and stored at $4^{\circ} \mathrm{C}$.

\subsection{Fermentation}

\subsubsection{Liquid state fermentation}

The fermentation medium containing (w/v) $0.2 \%$ naringin, $0.5 \%$ glucose, $0.7 \%$ peptone, $0.1 \%$ yeast extract, $0.05 \% \mathrm{KH}_{2} \mathrm{PO}_{4}, 0.01 \%$ $\mathrm{MgSO}_{4} .7 \mathrm{H}_{2} \mathrm{O}$ and $0.07 \% \mathrm{ZnSO}_{4} .7 \mathrm{H}_{2} \mathrm{O}, 0.07 \% \mathrm{CuSO}_{4} .5 \mathrm{H}_{2} \mathrm{O}$, $0.07 \% \mathrm{FeSO}_{4} \cdot 7 \mathrm{H}_{2} \mathrm{O}$ was used. The $\mathrm{pH}$ was adjusted to 6.0 (Navaratnam et al. 2003). Twenty five $\mathrm{mL}$ of the sterilized liquid medium was takeninto $100 \mathrm{ml}$ conical flask and 6day old cultures of each organism from potato dextrose agar (PDA) medium was inoculated in the liquid fermentation medium and allowed for fermentation at $200 \mathrm{rpm}$ in room temperature until $9^{\text {th }}$ day. The spores were taken out using sterile $0.85 \% \mathrm{NaCl}$ solution and spore size was adjusted as $10^{8}$ spores $/ \mathrm{ml} .1 \mathrm{ml}$ of spore solution was inoculated on duplicate fermentation medium of each fungal strain under aseptic condition. The fermented sample was withdrawn for the enzyme assay at $7^{\text {th }}$, 8 th and $9^{\text {th }}$ day. One unit of naringinase activity is defined as the amount of enzyme that produces $1 \mu \mathrm{mol}$ of reducing sugar in 1 minute at $\mathrm{pH} 5$ and $60^{\circ} \mathrm{C}$ with $10 \mathrm{gL}^{-1}$ naringin.

\subsubsection{Solid state fermentation}

The solid state fermentation was carried out for selected to compare the enzyme activity with liquid fermentation because of limited facilities and use of less expensive agricultural waste materials to make cost effective production. Fermentation medium contained 2:10 ratio of paddy husk and liquid medium. Twenty grams of paddy husk was inoculated with $1 \mathrm{ml}$ of the spore suspension with $10^{8}$ spores $/ \mathrm{ml}$ of the selected fungal strain Rhizophus stolonifer in $100 \mathrm{ml}$ liquid medium at $\mathrm{pH} 6.0$ and allowed to ferment for 7 days in room temperature. Sample was withdrawn and filtered and the filtrate was used for the enzyme assay. Duplicate was also maintained.

\subsection{Enzyme assay}

Enzyme assay was done based on the modified Miller (1959) method developed by Roy and Uddin (2004). Naringinase enzyme has $\alpha$-L-rhamnosidase and $\beta$-D-glucosidase that hydrolysis flabelliferin into glucose as end product. The glucose is a reducing sugar that has aldehyde group. This group reduces 3,5-dinitrosalicylic acid (DNS) to orange coloured 3-amino, 5 nitrosalicylic acid in alkaline medium on boiling and oxidizes itself to carboxylic group. Sodium potassium tartarate helps to fix the colour of 3 amino 5-nitrosalicylic acid and intensity of the orange colour developed is proportional to the concentration of reducing sugar present in the solution. Based on this principle, the activity of naringinase was determined by glucose standard curve.

\subsubsection{Liquid fermented sample}

The sample was withdrawn from liquid fermentation medium after $7^{\text {th }}, 8^{\text {th }}$ and $9^{\text {th }}$ day of incubation. The sample was centrifuged at 10000 rpm for 20 minutes. The supernatant was taken as crude enzyme for determination of naringinase activity. Duplicates and controls were also kept for each sample. $0.25 \mathrm{ml}$ of substrate that contain $0.5 \%$ naringin at $\mathrm{pH} 5.0$ in citrate buffer was taken and allowed for pre-incubation for $3 \mathrm{~min}$ at $50^{\circ} \mathrm{C}$ and simultaneously enzyme also was subjected to pre incubation. Then $0.25 \mathrm{ml}$ of enzyme (supernatant) was added to each test except control. It was allowed to reaction at $50^{\circ} \mathrm{C}$ for $10 \mathrm{~min}$. Then $0.5 \mathrm{ml}$ of DNS solution was added immediately to stop the reaction. Finally the container was boiled and cooled and then $5 \mathrm{ml}$ of sterilized distilled water was added and the volume was made to $6 \mathrm{ml}$. After $3 \mathrm{~min}$ of pre incubation $0.5 \mathrm{ml}$ of DNS solution was added then boiled and it was allowed to cool and after that $5 \mathrm{ml}$ of sterilized distilled water was added and this set up was used as control. Test and controls were stirred before the reading by using spectrophotometer at 550nm (Navaratnam et al, 2003, Sinthuja et al. 2016, Keerthini et al. 2016).

Unit of enzyme activity $(\mathrm{U} / \mathrm{ml})$ : Amount of naringin $(\mu$ mole $)$ which can be hydrolyzed by $1 \mathrm{ml}$ of crude enzyme naringinase in 1 minute.

Enzyme activity was determined by the following equation,

Enzyme Activity = concentration of glucose standard $(\mathrm{mg})$ xabsorbance of test $\times 1000$

Absorbance of standard glucose xvolume of enzyme solution(ml)

$x$ incubation time $(\min ) \times 180$

\subsubsection{Solid fermented sample}

The culture filtrate was taken from solid state fermentation medium after $7^{\text {th }}$ day to find out enzyme activity. Enzyme assay was done by modified Miller method as same as liquid fermented sample and 1gram of solid substrate was taken from solid fermentation medium to analyze the moisture content which was carried out at $80^{\circ} \mathrm{C}$ until getting a constant weight. The enzyme activity of solid state fermentation was presented as unit (U) per gram of dry substrate.

\subsection{Identification of fungi}

Potato dextrose agar (PDA) slant and plates samples were prepared and maintained at $25^{\circ} \mathrm{C}$ for identification of selected fungal strain. Morphological characteristics were used to identify the fungi. The colony colour, sporangial shape and structures were observed from initial stage to maturity with naked eye and through microscope. The sporangiospore, Rhizoids, stolons and sporan- 
giophore were also observed under microscope. The spore size was measured with the help of stage microscope.

\section{Results and discussion}

\subsection{Isolation of naringinase producing strains}

In this study, natural Palmayrah wastes such as palmyrah pulp and decaying particles of the pulp in the sand were selected as source for the isolation of naringinase producing fungus. Primary screening was done by observation of culture medium. Five fungal strains / colonies changed the colour of the selective medium.
Secondary screening was done by measuring the naringinase enzyme production. It was five fungal strains from primary screening were selected as naringinase producers. Those strains were capable of producing extracellular naringinase enzyme in liquid fermentation media under no agitation. Among the isolated fungal strains, only five fungal strains were identified as naringinase producers and designated as PF1, PF2, PF3, PF4 \& PF5 - Fig 1). Higher enzyme activity was observed on the $7^{\text {th }}$ day for PF1 and PF4 and $8^{\text {th }}$ day for PF2, PF3 and PF5 (Table 1). PF4 showed highest naringinase activity $(1.769 \mathrm{U} / \mathrm{ml})$ at $\mathrm{pH} 5.0$ in citrate buffer when the temperature was kept at $50^{\circ} \mathrm{C}$.
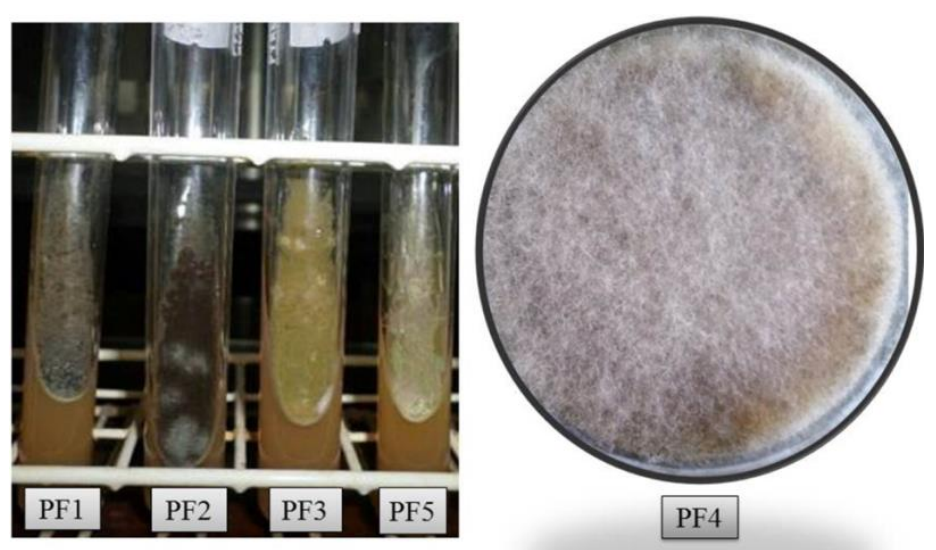

Fig. 1: Isolated Fungal Strains.

Table 1: Enzyme Activity of Isolated Fungal Strains in Liquid Fermentation Method

\begin{tabular}{llll}
\hline Organism & $6^{\text {th }}$ Day Activity (U/Ml) & $7^{\text {th }}$ Day Activity (U/Ml) & 1.375 \\
\hline PF1 & 1.536 & 1.653 & 0.877 \\
PF2 & 1.327 & 1.075 & 0.931 \\
PF3 & 1.701 & 1.711 & 1.359 \\
PF4 & 1.769 & 1.747 & 0.6 \\
PF5 & 1.023 & 1.055 & 0 \\
\hline
\end{tabular}

Naringin agar selective medium was used for the primary screening. The best naringinase producing strain was isolated from palmyrah fruit fiber and $1.656 \mathrm{U} / \mathrm{ml}$ of activity was obtained at $\mathrm{pH} 5.0$ in citrate buffer and at $50^{\circ} \mathrm{C}$ (Navaratnam et al, 2003). The activity of the selected strain was higher than previous organism isolated. The difference in the amount of enzyme production may be due to the variation of fungal strains, source and cultural conditions.

The easily available Palmyrah fruit pulp was selected as source to isolate the naringinase producing fungal strains and the natural diversity is important to adopt the organism to produce appropriate enzyme (Thammawat et al, 2008). In this study decayed palmyrah fruit pulp, fruit pulp that is buried in the soil and soil sample around the buried pulp were used to isolate the fungal strains (Table 2). Palmyrah fruit fiber was selected to isolate naringinase producing strains and 25 fungal strains were isolated from palmyrah fruit fiber as naringinase producing strains (Navaratnam 2003). Aspergillus flavus isolated from the wet soil in a poultry house produced naringinase (Radhakrishnan and Sampath, 2013). Aspergillus niger $\mathrm{BCC} 25166$ was proved to produce naringinase enzyme (Thammawat et al, 2008).

Table 2: Isolated Fungal Strains in this Study

\begin{tabular}{ll}
\multicolumn{2}{c}{ Table 2: Isolated Fungal Strains in this Study } \\
\hline Fungal Strains & Source \\
\hline PF1 & Soil Around Buried Fruit Pulp \\
PF2 & Buried Fruit Pulp \\
PF3 & Decayed Fruit Pulp \\
PF4 & Decayed Fruit Pulp \\
PF5 & Buried Fruit Pulp \\
\hline
\end{tabular}

Penicillium decumbens PTCC 5248 was reported as naringinase producing strain in liquid media when cultivated in medium containing naringin as carbon source (Norouzian et al, 2000). The carbon source could be considered as inducer for naringinase pro- duction. The naringin was the best inducer for the production of naringinase by Aspergillus niger MTCC 1344 than hesperidin, naringenin, rhamnose and rutin. Enzyme activity was optimum at $7^{\text {th }}$ day of incubation (Kumar 2015). Most Aspergillus strains (A. foetidus, A. niger HPD2, A. niger) showed higher enzyme activity on the $8^{\text {th }}$ day of incubation (Mendoza-Cal, 2010). Naringinase enzyme activity was higher on the $7^{\text {th }}$ day of incubation.

\subsection{Solid state fermentation of selected strain}

When the selected fungal strain (PF4) was subjected to solid state fermentationusing paddy husk as support, highest naringinase enzyme activity ( $269.84 \mathrm{U} /$ gram of dry substrate) was obtained on the $7^{\text {th }}$ day at room temperature under no agitation.

There have been no reports available for the production of naringinase by Rhizophus stolonifer by using paddy husk as substrate in solid state fermentation but potential to have produce enzyme naringinase by filamentous fungi in solid state fermentation. The solid state fermentation process was best method over conventional submerged fermentation because of higher yield of secondary metabolites and enzymes. Certain enzymes and secondary metabolites can only be produced under solid state fermentation system (Barrios-González and Tarragó-Castellanos, 2015). The production of any compound by using microorganism must be considered with the facilities, amount of outcome, cost effectiveness and also satisfaction of the compound characteristics (Pandey et al, 1996). The growth and metabolic activity of the microorganism can be facilitated by solid substrate which absorbs the moisture and provides better utilization of substrate by microorganisms (Pandey 1992).

The naringinase enzyme was produced by filamentous fungus using grape fruit rind and orange rind as substrates under solid 
state fermentation and the grape fruit rind was best substrate than orange rind (Mendoza-Cal 2010). The Aspergillus niger MTCC 1344 produced high levels of naringinase enzyme in a short period about 96 hours of incubation when solid state fermentation with rice bran was done ( $\mathrm{Ni}$ et al, 2011). The production of $\alpha-\mathrm{L}$ rhamnosidase by Aspergillus terreus CECT 2663 was highest in solid state fermentation using sugar cane bagasse as substrate (Elinbaum et al, 2002). Similarly different naringinase producing fungal types from different species were isolated from citrus maxima fruits (Keerthini et al, 2016 a, b) and decaying Palmyrah fruit pulp in soil (Sinthuja et al, 2016). Glucoamylase production by Aspergillus niger CFTRi 1105 was highest when using paddy husk as support (Arasaratnam et al, 2001). Xylanase production by Bacillus pumilus in solid state fermentation using paddy husk as support yielded significantly higher production of enzyme than the usual liquid media (Kapilan and Arasaratnam, 2011). The Rhizophus stolonifer was used to produce cellulose-free alkaline xylanase in solid state using wheat bran as substrate (Goulart 2005). Diverse studies indicate that potential and possibilities to get commercial level of enzyme (naringinase) production by filamentous fungus using solid state fermentation (paddy husk).

\subsection{Identification of selected fungal strain}

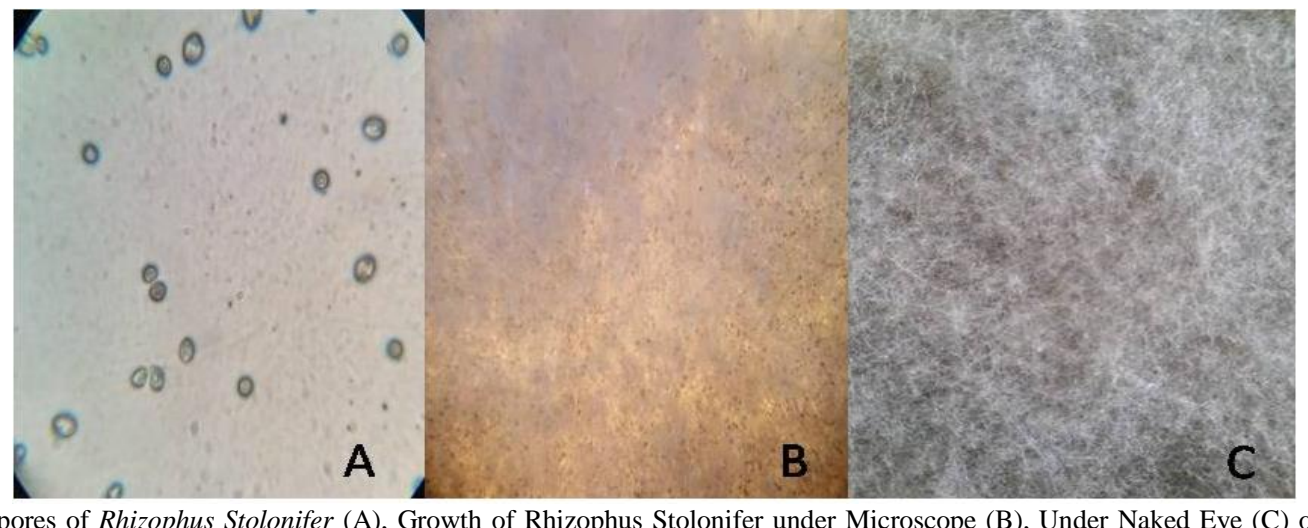

Fig. 2:Sporangiospores of Rhizophus Stolonifer (A), Growth of Rhizophus Stolonifer under Microscope (B), Under Naked Eye (C) on Potato-Dextrose Agar (PDA) Medium.

\section{Conclusion}

Among the five naringinase producing fungal strains isolated from Palmyrah pulp, the strain that was confirmed as Rhizohpus stolonifer showed highest naringinase enzyme activity in the liquid fermentation system $(1.769 \mathrm{U} / \mathrm{ml})$ and in the solid state fermentation system using paddy husk asa support (269.84U/gram of dry substrate). Solid phase production of naringinase with the support of paddy husk for this fungus would be an efficient cost effective method for the production of large scale naringinase.

\section{Acknowledgement}

Authors sincerely thank the University of Jaffna for awarding the Research Grant to Dr.S.Vasantharuba, Department of Agricultural Chemistry. Technical support and suggestions provided by Mr. V. C. Anpalagan, Mr. P.T.J. Jashothan and Mr.A.Thananchayan, University of Jaffna is highly appreciated.

\section{References}

[1] Arasaratnam, V., Mylvaganam, K., \&Balasubramaniam, K. (2001) Glucoamylase production by Aspergillusniger in solid state fermentation with paddy husk as support. Journal of food science and technology, 38(4), 334-338.

[2] Barrios-González, J., and Tarragó-Castellanos, M. R. (2015). SolidState Fermentation: Special Physiology of Fungi.
Colonies of selected fungi $\left(\mathrm{PF}_{4}\right)$ was white at the initial stage, became brownish black by sporangia. Sporangia were also white $\&$ transparent at initial stage when observed through light microscope then the sporangial colour turned as black at maturity. Stolens spread quickly and functioned as anchor on the substrate with the help of rhizoids. The sporangiospores were brown in colour with oval and irregular round under light microscope. The size of the sporangiospore was around 8.6- $13 \mathrm{~nm}$. Based on these morphological characters the selected fungi $\left(\mathrm{PF}_{4}\right)$ was tentatively identified as Rhizopus stolonifer.

The colonies of Rhizopus stolonifer on potato dextrose agar at $25^{\circ} \mathrm{C}$ were white and became heavily speckled by the presence of sporangia which was white\& transparent at initial stage then turned to brownish black. Sporangia were globose or subglobose and the colour was white at first and then turned black when it bears many spores. Sporangiospores were $8.2-18.8 \mathrm{~nm}$, irregular, round, oval, elongate, angular brownish black streaked. Stolens spread quickly and rhizoids helped to support the substrate. (Kwon et al, 2001 and Hernández-Lauzardo et al, 2006). The mycelia found on the growth surface was white to gray and arial mycelia was originated from rhizoids and stolen (CO 2011). Based on the morphological, cultural and biochemical tests the strain $\mathrm{PF}_{4}$ was identified as Rhizophus stolonifer. 
[12] Keerthini, S, Kapilan, R., Vasantharuba, S. (2016b). Optimization of naringinase production from Aspergillusflavus in solid state fermentation media using citrus peel as support, Scholars Academic Journal of Biosciences, 4 (6), 535-543. DOI: 10.21276/sajb.2016.4.6.16

[13] Kumar, V. V. (2015). Comparative studies on inducers in the production of naringinase from Aspergillusniger MTCC 1344. African Journal of Biotechnology, 9(45), 7683-7686.

[14] Kwon, J. H., Kang, S. W., Kim, J. S., \& Park, C. S. (2001). Rhizopus soft rot on cherry tomato caused by Rhizopusstolonifer in Korea. Mycobiology, 29(3), 176-178.

[15] Mendoza-Cal, A., Cuevas-Glory, L., Lizama-Uc, G., \& OrtizVázquez, E. (2010). Naringinase production from filamentous fungi using grapefruit rind in solid state fermentation. African Journal of Microbiology Research, 4(19), 1964-1969.

[16] Navaratnam, P., Ketheeswary, N., Senthuran, A., \&Arasaratnam, V. (2003). Preliminary studies on the isolation of naringinase producing fungus.

[17] Ni, H., Li, L., Xiao, A., Cao, Y., Chen, Y., \&Cai, H. (2011). Identification and characterization of a new naringinase-producing strain, Williopsiscalifornica Jmudeb007. World Journal of Microbiology and Biotechnology, 27(12), 2857 2862.http://dx.doi.org/10.1007/s11274-011-0766-7.

[18] Nikawela, J. K., Abeysekara, A. M., \&Jansz, E. R. (2011). Flabelliferins-steroidal saponins from palmyrah (Borasus flabellifer L.) fruit pulp isolation by flash chromatography, quantification and saponin related activity. Journal of the National Science Foundation of Sri Lanka, 26(1).http://dx.doi.org/10.4038/jnsfsr.v26i1.3080.

[19] Nikawala, J. K., Jansz, E. R., Baeckstrom, P., Abeysekera, A. M. \&Wijeyaratne, S. C. (2000). Flabelliferins of naringinase debittered palmyrah fruit pulp.

[20] Norouzian, D., Hosseinzadeh, A., Inanlou, D. N., \&Moazami, N (2000). Production and partial purification of naringinase by Penicilliumdecumbens PTCC 5248. World Journal of Microbiology and Biotechnology, 16(5), 473.http://dx.doi.org/10.1023/A:1008962131271.

[21] Pandey, A. (1992). Recent process developments in solid-state fermentation. Process Biochemistry, 27(2), 109117.http://dx.doi.org/10.1016/0032-9592(92)80017-W.

[22] Radhakrishnan, I., \&Sampath, S. Isolation and characterization of enzyme naringinase from Aspergillusflavus. International Journal of Advanced Biotechnology and Research, 1(4), 208-212.

[23] Ribeiro, M. H. (2011). Naringinases: occurrence, characteristics, and applications. Applied microbiology and biotechnology, 90(6), 1883-1895.http://dx.doi.org/10.1007/s00253-011-3176-8.

[24] Sinthuja, K., Kapilan, R., Vasantharuba, S. (2016). Optimization of naringinase production by Rhizophus stolonifer in solid state fermentation media using paddy husk as support, Scholars Academic Journal of Biosciences, 4(6), 507-514. DOI 10.21276/sajb.2016.4.6.10

[25] Sumuduni, K. A. V., Jansz, E. R, and Wickremasekara, N. T. (2002). A review of the chemistry and biochemistry of seed shoot flour and fruit pulp of the palmyrah palm (Borassus flabellifer L.).

[26] Thammawat, K., Pongtanya, P., Juntharasri, V., \&Wongvithoonyaporn, P. (2008). Isolation, preliminary enzyme characterization and optimization of culture parameters for production of naringinase isolated from Aspergillusniger BCC 25166. Kaestsart J Nat Sci, 42, 61-72. 